Article

\title{
Sweden Backcasting, Now?-Strategic Planning for Covid-19 Mitigation in a Liberal Democracy
}

\author{
Jouni Korhonen ${ }^{1, *}$ and Birk Granberg ${ }^{2}$ \\ 1 Department of Sustainable Production Development and CE@KTH Initiative, KTH Royal Institute of \\ Technology, 11428 Stockholm, Sweden \\ 2 Independent Researcher, 15102 Södertälje, Sweden; birkg@kth.se \\ * Correspondence: jounikor@kth.se; Tel.: +46-70-087-70-45
}

Received: 15 April 2020; Accepted: 14 May 2020; Published: 19 May 2020

\begin{abstract}
Sweden is applying the herd-immunity as its main natural science strategy to combat the Covid-19 pandemic. This has been communicated in a transparent manner. Small groups of young(er) people of up to approximately 50 individuals are subject to a bigger risk of infection than others. The objective of this paper is to make a case for the argument, that alongside herd-immunity, Sweden is using the social science originated planning approach: backcasting. The government has not been transparent on backcasting. The authors present the use of backcasting only as an argument based on available data and authors' reasoning. A backcasting exercise for the case of the Swedish economy is constructed. This frame outlines five interdependent levels with which a national economy can apply what this paper calls a backcasting herd-immunity approach in its COVID-19 policy. The authors further suggest how it is possible to use social science, natural science and political ideology as complementary in COVID-19 mitigation in particular and in sustainability strategies in general.
\end{abstract}

Keywords: herd-immunity; backcasting; transdisciplinary research; circular economy; political ideology

\section{Introduction}

Covid-19, the novel coronavirus, is now (date of submission of the revised manuscript, 5 May 2020) the most acute example of unsustainable societal development within the biosphere. The virus does not discriminate between different individuals, between groups of people, between ages, and exceeds man-made, ethnic and physical boundaries including those related to organizational and sectoral. The novel coronavirus is still relatively unknown to science. It affects all the three dimensions of sustainability: ecological, economic and social. In USA, the African American and Hispanic communities face relatively higher risk of being infected, hospitalized or admitted to intensive care units than white people. In the world, emissions are decreasing due to economic shutdowns. The short-term environmental impact of reduced economic and industrial activities as well as reduced consumption is reduced resource consumption, decreasing emissions and wastes. In terms of the economic dimension, on 15 April 2020 in USA, about 20\%-25\% unemployment projections were announced due to the virus.

Coronavirus is an example of unforeseen, dynamic and difficult to manage phenomena, problems and disruptions that occur in complex adaptive systems (CAS, see, e.g., [1-4]). The focus system of sustainable development projects in general is a CAS: the global society within the biosphere [5-7]. Planning for system maintenance, dependability, recovery, persistence, sustainability, adaptability and resilience is a difficult task in such systems (see e.g., [1,3]). This means that COVID-19 mitigation efforts require interdisciplinary (between diverse scientific disciplines) and transdisciplinary (cooperation 
between sciences and societal stakeholders including policy-makers, industrial manufacturers and business leaders) types of work.

Backcasting as a strategic planning approach originates from defense policy and military operations. Often in a time of war, the only possibility to stay alive is to plan for winning. This is if one does not regard surrender as an option. Even if the current situation seems desperate, the planner must define the strategic vision and overall objective of the plan based on a desired future outcome of the plan and its implementation-the win. In Robért et al. ([5,6]), backcasting is compared to traditional forecasting. Unlike forecasting, backcasting takes the desired future successful landing place as the basis for defining the overall objective and strategic vision of the planning endeavor. The current situation is only allowed to affect the pace of the required transition, not the overall direction.

Backcasting can be useful in situations where a radical, fundamental and paradigmatic transformation is needed (see e.g., [5,6,8-13]). Desirable futures cannot solely be derived from current and past problems. Description of the expected trends may not support ambitious objectives. The expected trends of societal development derived from the present situation may give pessimistic predictions and lock-in development paths hampering radical innovations (see, e.g., [14]). Note that still some $75 \%$ of the global energy production relies on non-renewable, emissions intensive and often imported from politically turbulent areas such as the fossil fuels coal, oil and natural gas [12,13]. Radical disruptions in the path dependency of the global energy system are needed.

Sweden has received lot of attention in the world because of its usage of the natural science herd-immunity approach in COVID-19 mitigation. Sweden has a high rate of per capita deaths compared to most of the world. Sweden is keeping schools, restaurants, bars, pubs, nightclubs, hair salons and the like open although the per-capita dead rate is very high (see later on in the paper). We use the publicly available data from the government of Sweden published on the submission date of the revised manuscript (5 May 2020). The paper presents simple projections based on the data. The projections and data are discussed in the context of the general discourse on governmental policies and strategies in COVID-19 mitigation. For example, the discourse in some of the leading media channels such as CNN are used. Literature from interdisciplinary sustainable development sources, such as CAS, resilience science, sustainability governance, policy and management, corporate social responsibility and circular economy etc. are integrated to the discussion in the manner of explorative conceptual research and brainstorming.

The objective of this paper is to make a case for the argument, that alongside herd-immunity, Sweden is using the social science originated planning approach; backcasting. It seems that the Swedish government is somewhat unclear, vague and inconsistent in its communication, perhaps not even thoroughly aware itself, of the hidden theory of backcasting behind its response. It is conceivable that this is due to the interdisciplinary (between sciences) and transdisciplinary (between science and societal stakeholders) nature of backcasting as a strategic planning approach. It should also be noted that the novel Corona virus as a natural phenomenon is still relatively unknown to science. All sustainability issues are inherently complex, interdisciplinary and transdisciplinary [15].

The structure of the presentation is as follows. We start with an overview of backcasting as a strategic planning approach to public policy and business management. Section 3 presents the current main COVID-19 numbers based on the publicly available data from the government of Sweden (e.g., the official internet pages of the government). The section will also discuss the numbers. In Section 4, the herd-immunity and backcasting concepts are integrated. Section 5 will argue that when investigating the Swedish experiment on the Corona virus, three pillars are central; (1) natural science, (2) social science and (3) political ideology. Discussions are presented in Section 6. Conclusions are derived accordingly in Section 7.

\section{On Backasting as a Strategic Planning Approach}

Backcasting (see e.g., $[5,6,16])$ is helpful in cases where a radical, fundamental and paradigmatic transformation is required. Backcasting has been found to be fruitful in sustainable development work 
in complex adaptive systems $[4,17,18]$. This is, for example, due to its ability to simultaneously take into account both the long-term strategy and the acute needs of the present situation. It is beyond the scope of this paper to further consider the inherent characteristics of backcasting in sustainable development work. The current COVID-19 crisis requires a radical transition in society. In the short term, a vaccination or effective treatment is required. In the short and long term, the interaction of society and biosphere should be transformed onto a level that is sustainable according to the three dimensions of sustainability: environmental, economic and social.

The more traditional method used in strategic planning or in future studies is forecasting. Forecasting may be best suited for planning for and implementing incremental, small and technical changes. What we mean with small changes is illustrated, for example, by Ehrenfeld in his elaboration on the use of the classic Kuhnian (see, e.g., [19]) model of paradigm shifts in sustainable development.

In the Kuhnian two-stage model of paradigm shifts, the first stage is about radical and fundamental changes. Here norms, values, world-views and metaphors are important. The second stage is about incremental, small and technical changes. In sustainability, these could mean, for example, using new allocation rules in the impact assessment of environmental life cycle assessment (LCA) or instead of choosing the traditional LCA apply the more recent consequential LCA. Another example of an incremental change toward sustainability is increasing the efficiency (per unit of output, a relative ratio, see, e.g., $[17,20])$ of the energy/fuel use in production and manufacturing. This can create a situation where the overall energy use increases due to rebound effects [21,22]. Consumption increases extensively, because of lower prices of end-products occurring as production costs decrease with production efficiency.

It seems logical that backcasting can be fruitful for transformations such as those needed for achieving more sustainable development. Mitigating Covid-19 is an example of the many problems unsustainable development presents to the global society. Fundamental shifts are needed. It is argued here, that perhaps without complete awareness, the government of Sweden is using backcasting or backcasting-type thinking in its strategy to mitigate Covid-19. In terms of natural science, Sweden is using herd-immunity as the national mitigation strategy.

Bars and restaurants where young people gather are allowed to be kept open. Sweden emphasizes the physical distancing of the elderly. All the schools are kept open. The publicly communicated and available message from the government (as of 5 May 2020) is that the government believes the herds of young people will develop immunity. The herds could then in a sense "surround" the old people. The surrounding implies that the immune and healthy young people and their groups create a type of a shield that protects the elderly. This is a high risk-high potential reward strategy say the many in the media. Additionally, international news channels such as $\mathrm{CNN}$ have been vocal concerning the risks of herd-immunity. For herd-immunity to achieve its fullest potential, some $70 \%$ or $80 \%$ of the population should become infected (public communication from the Swedish government's leading COVID-19 expert Dr. Andreas Tegnell). For example, in such a situation, when a young person, who has a socially active lifestyle, goes out, this person has a very low risk of getting an infection or infecting others.

Backcasting theory first defines the successful and desirable future situation, the outcome of strategic planning, policy, effective governance and management (see e.g., $[5,6,16])$. This can read, for instance as follows: "In 20 years from now we are where we want to be regardless of the present situation and its challenges, problems, strengths, weaknesses, opportunities and threats." One then starts to come back from that desired landing place step-by-step. Where do we need to be in 18 years, in $16,14,12,10,8,6,4,2$ and where are we know? The direction is reversed "back to the future". Now the SWOT analysis (strengths, weaknesses, opportunities and threats), a traditional forecasting method, is used alongside backcasting. What do we need to do to achieve the outlined path, in particular, to achieve the identified step one, i.e., in this hypothetical example, the situation two years from now? It often happens that the second or third etc. best investment/decision/action alternative from the traditional SWOT perspective is preferred. This is if it secures the overall direction towards the strategic vision and overall objective better than the best SWOT-based alternative. 
In this paper's backcasting exercise, the system under focus is the country of Sweden. Its current situation's SWOT is only allowed to affect the pace of the required transition. SWOT is not allowed to influence the overall direction of the transition. Desirable futures cannot solely be derived from current and past problems. But in the practical actions required to achieve each step toward the objective (like those taken every two years in the simplified example here), SWOT is relevant.

The next section shows the currently available public data from the government of Sweden concerning the basic Covid-19 numbers on 5 May 2020. After that, we will argue that Sweden is, perhaps without being thoroughly aware of its strategy, using also the social science backcasting planning approach in its governance. Furthermore, Sweden is among the very few countries in the world (to authors knowledge on the date of submission of this paper) that apply the natural scientific herd-immunity method in the Covid-19 mitigation. It should be noted that all data, materials and information concerning the coronavirus case must be judged with a critical eye due to novelty of the previously unknown virus and the lack of learning on how to mitigate the virus and its many different economic, environmental and social implications.

\section{On the Swedish Covid-19 Case on 5 May 2020}

Herd-immunity can be valuable in the long-term perspective of the adaptation of the population to the pandemic. It is possible that in one form or another a second wave will reemerge in the coming seasons. The "Swedish Experiment" has received/is receiving lot of attention around the world.

The Swedish government communicates that it views herd-immunity as the best available way to reduce the risk of the health care system running out of capacity to cope in the Swedish context. Many other countries including USA, Finland, Denmark, Norway etc. have criticized the Swedish government's response to the pandemic. This section presents the latest data available to us from the official Swedish government internet pages. We have used the data available on the date of submission of this revised manuscript, 5 May 2020. We use the publicly available data from the government of Sweden. The section presents simple projections based on the data.

In the subsequent sections of the paper, the projections and data are discussed in the context of the general discourse on government policies and strategies in COVID-19 mitigation in the world. For example, the discourse in some of the leading media channels such as CNN are used. Literature from interdisciplinary sustainable development sources are integrated to the discussion. We want to emphasize that due to lack of knowledge and virtually no practical experience on mitigating the new COVID-19 virus, our thesis is mainly aimed at initiating discussion and dialogue on the phenomenon of COVID-19 in the society and on its mitigation. The phenomenon is interdisciplinary and transdisciplinary crossing boundaries between science and societal stakeholders and those between different societal sectors. We feel that, at this point of learning and knowledge, this kind of dialogue and discussion can be fruitful for developing more focused research questions and hypotheses in the future. (see Figure 1)

The estimation is based on data from the government of Sweden (available 5 May 2020). The black color shows a projection of cases based on the data gathered before the 14th of March when the government decided to no longer test every suspected case. It should be stated that this is not a prediction of/for where we are at today, more of an indication of a worst case scenario of cases Sweden might have missed earlier during the outbreak, because of not doing nationwide testing like e.g., South Korea did. After the 14th of March only those people assumed to be in need of intensive care (IC) were tested. The increase rate is assumed to be 1.3 per day. The early (prior to 14th March) weighted average (weighted against the total amount of cases and days) gives a value of 1.33. However, when comparing the spread rate from, for example South Korea and Italy, 1.3 seems accurate enough for this estimation. Green color shows the data of confirmed cases according to FHM (The Public Health Agency of Sweden). Blue and yellow depict a projection on what the amount of cases should be in Sweden based on deaths (Blue is FHM. Yellow is Worldometer). We have assumed that it takes 14 days from infection to die from Covid-19 and it has a mortality rate of $2 \%$. The increase rate is 
taken from a weighted average of the daily increase weighted against the total amount of deaths. (see Figure 2)

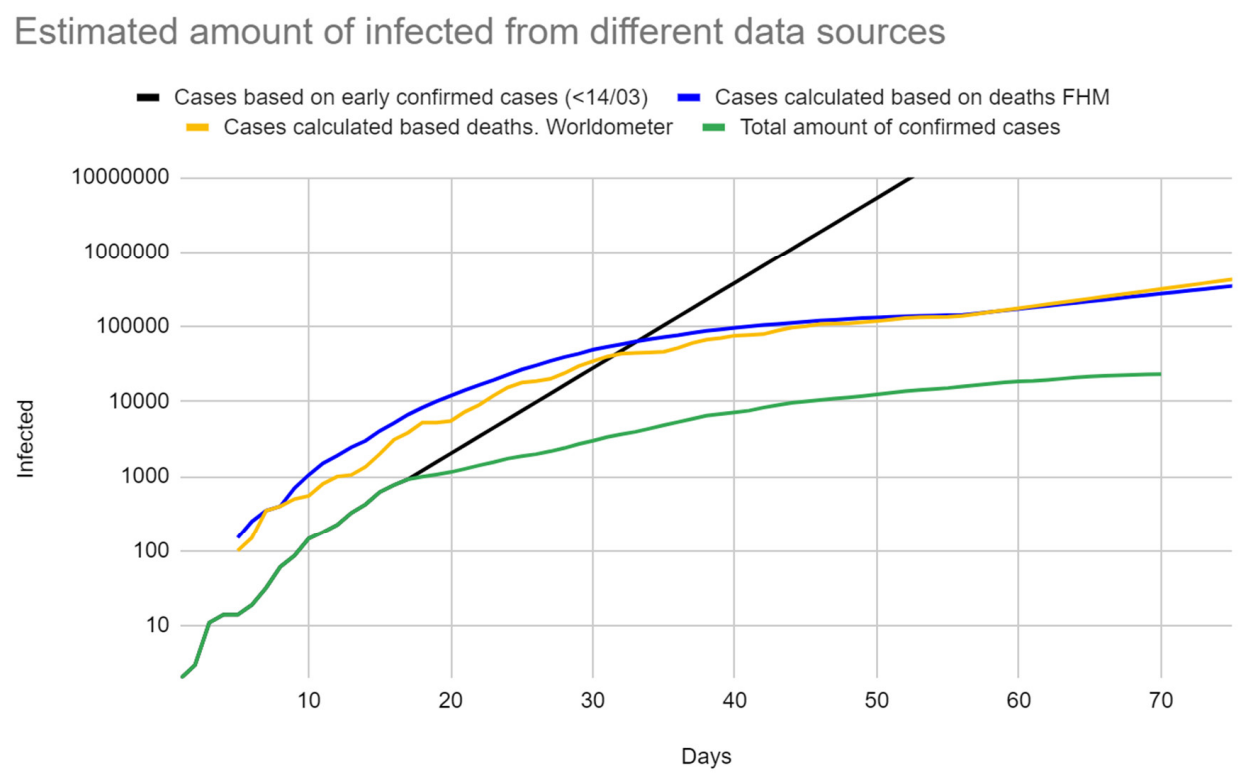

Figure 1. Estimated number of infected individuals in Sweden compared to days since 26 February 2020.

Total deaths compared to admitted to IC vs. days since February 26th, 2020

- FHM total deaths $=$ Worldometer total deaths $=$ Total IC patients (recovered not excluded)

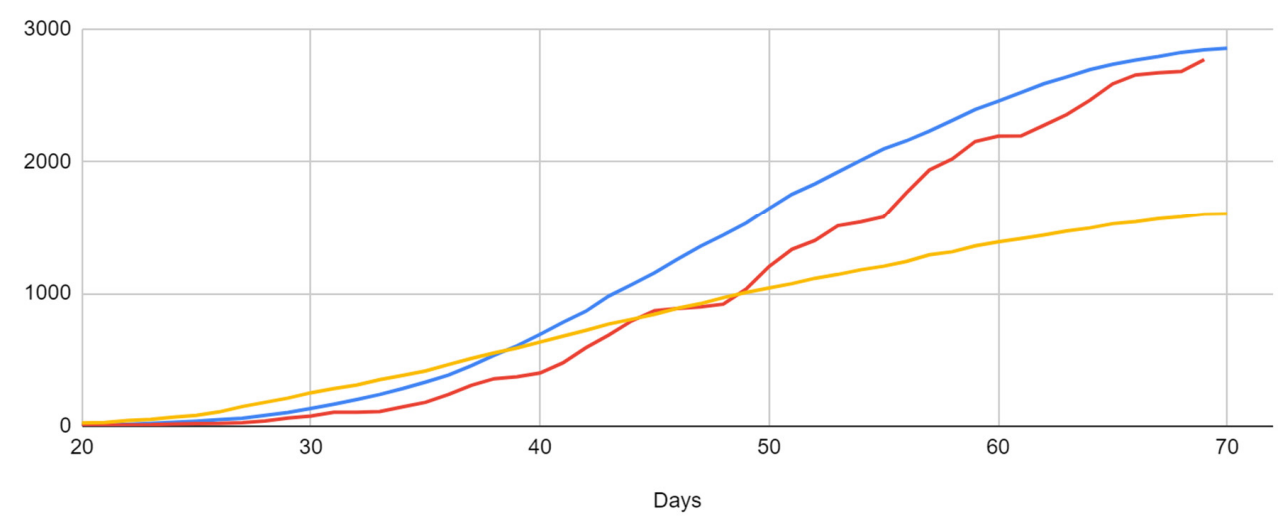

Total deaths compared to total amount admitted to IC vs. days since February 26th, 2020

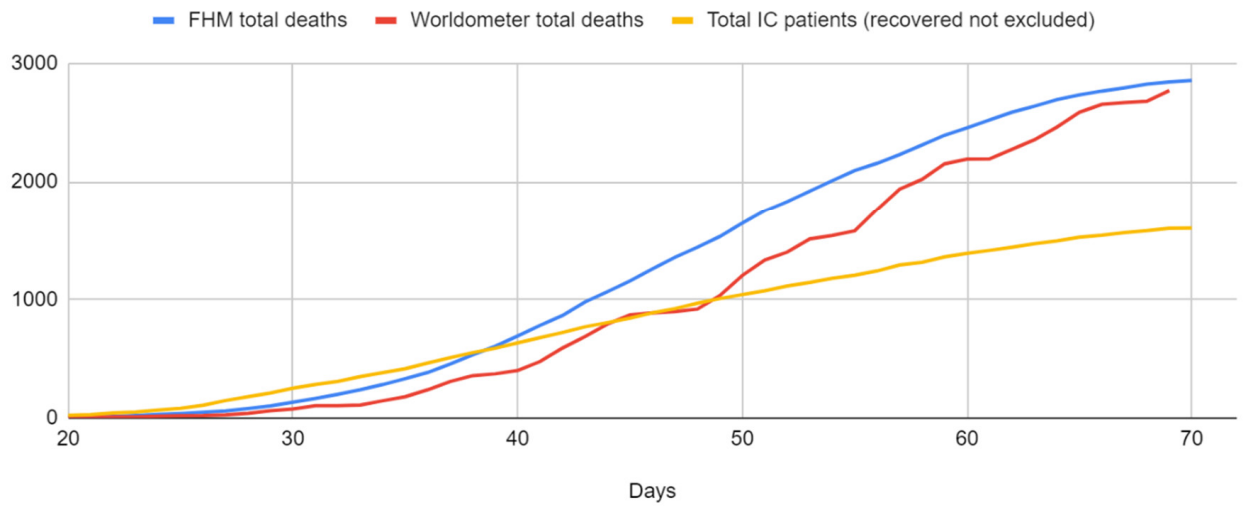

Figure 2. Total deaths compared to the number of individuals admitted to IC. 
Total deaths are compared to the number of individuals admitted to intensive care (IC). This is according to the data published by FHM. (see Figure 3)

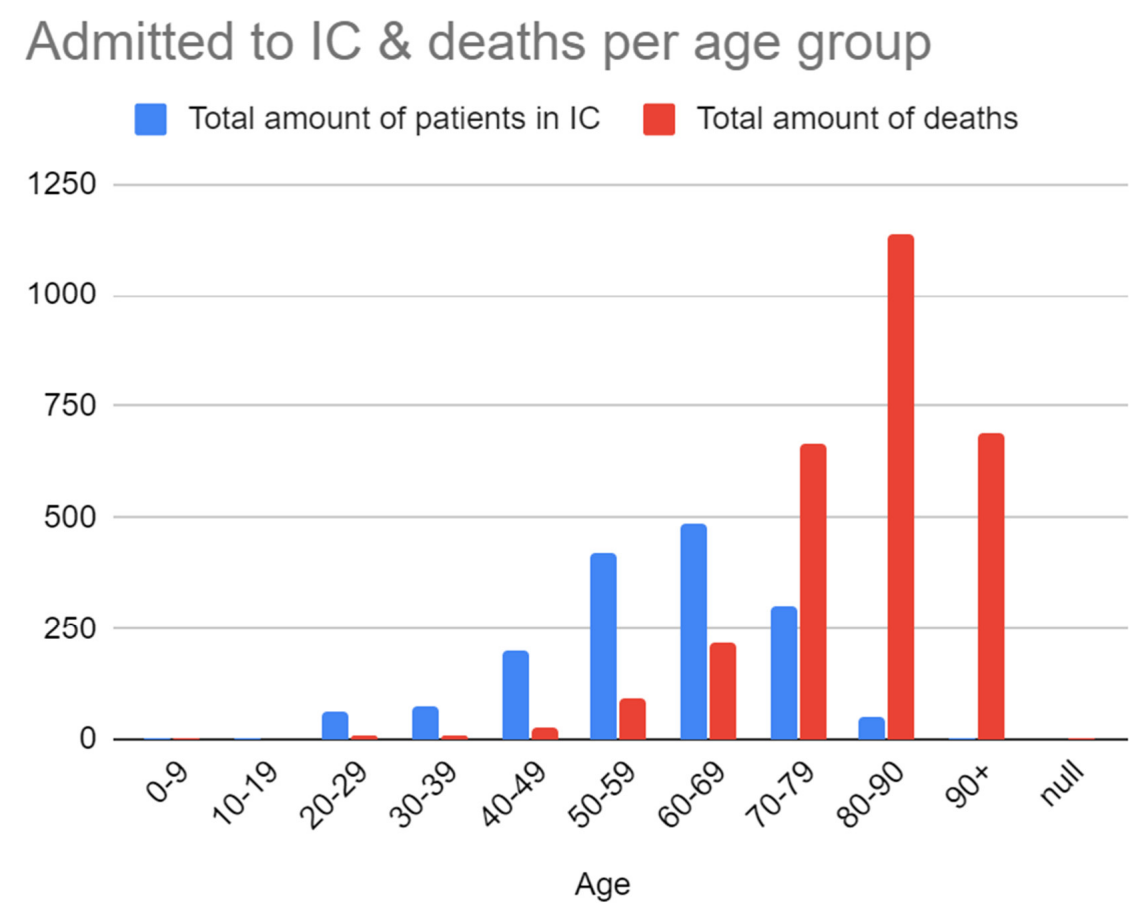

Figure 3. The number of individuals admitted to IC in Sweden and the deaths per age group based on the data available from the government of Sweden on 5 May 2020.

Note the very large discrepancy between IC patients compared to deaths in the older age groups. This indicates that most of these people do not ever make it to or are not admitted to IC. This fits with the guidelines "National Principles for Prioritising Within IC During Extraordinary Circumstances" document distributed to hospitals in Sweden on the 25th of March 2020 by the National Social Welfare Board of Sweden. (see Figure 4)

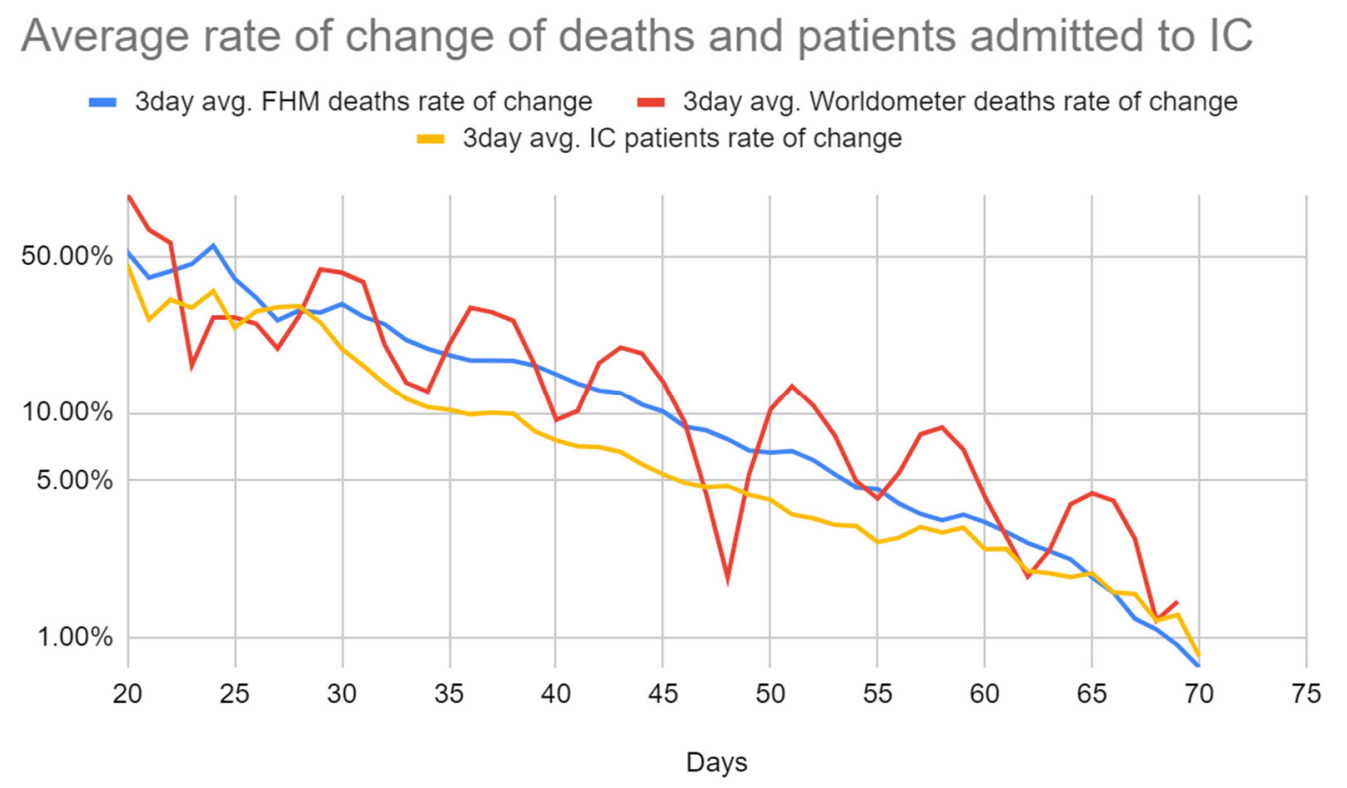

Figure 4. The Public Health Agency of Sweden (FHM) rate of change in deaths, Worldometer rate of change of deaths and rate of change of patients admitted to IC. 
The figure shows the average rate of change over the previous three days. This is done in order to reduce the noise in the data. Here we can see the way Worldometer reports the data collected from the regions in Sweden. It is not fully reported during every red day (national holidays, Sundays). The point to consider here is that the figure depicts a development that supports the herd-immunity approach Sweden is using. That is, the figure shows a development that challenges what the majority of the expressed critiques of the Swedish approach state. At least for now and with very limited experience and data we have, herd-immunity actually does seem to work. We can see what can be called an exponential decrease in the rate of increase of deaths and IC admitted patients.

\section{Herd-Immunity in Backcasting Theory}

\subsection{Integrating Herd-Immunity and Backcasting in the COVID-19 Case}

This section shows that the herd-spread or herd-immunity approach from natural science fits within the social science planning theory of backcasting when considering the actions of the government of Sweden. The section will construct a hypothetical model or a backcasting exercise integrating herd-immunity and backcasting. Although the Swedish government has not communicated that this is what they are doing, we believe a case can be made for the argument that they are consciously or unconsciously doing this or something similar. Because of the data and information available for us on COVID-19 mitigation is limited, only time will tell whether our hypothesis is correct. That is, the argument here is that the Swedish Experiment that has and is receiving lot of international attention, is an interdisciplinary one. Social science originated backcasting and natural science herd-immunity jointly and serving as complementary approaches, they constitute the COVID-19 mitigation of the government.

As noted earlier, we can present this message only as a hypothesis. This is because the government has not been open on backcasting. In other words, our argument is a conceptual construction derived from the available quantitative data in Sweden and from the publicly available governmental communication. Our hypothesis is also integrated to several bodies of sustainability and sustainable development literature, e.g., complex adaptive systems, strategic planning, ecological economics, sustainability politics and policy, sustainability governance and management, corporate social responsibility, circular economy etc. COVID-19 and the efforts for mitigating the devastating effects of this virus are phenomena that affect and are affected by all the three dimensions of sustainable development: ecological, economic and social.

\subsection{A Backcasting Herd-Immunity Exercise}

The backcasting herd-immunity exercise defines the overall objective based on a desirable future situation. This successful landing place out from the crisis is a situation in 20-26 months from now (date of the revised manuscript; 5 May 2020). The vision is optimistic for the purpose of making the argument.

In our exercise, we imagine that the desired situation is a situation in 20-26 months. In this vision, all those in need of COVID-19 vaccination in Sweden are actually receiving the vaccination. The vaccination project of all in need has been completed at the 26-month mark. With 'those in need' we mean that some parts of the population have an immunity, or because of some other currently unknown reason, parts of the population do not need the vaccine.

It may be possible that the currently starting antibody testing will identify immunity or will help to develop functioning blood transfusion measures. In the national media and in the official communication by the government, it has been stated that the antidote tests will be conducted in accordance with human rights. This means that, for example, one's level of income or social status is not a criterion when the health-care system of Sweden is selecting the individuals that will be tested for antibodies. 
It is also possible that Ebola drugs such as Rembesivir or even malaria medication-type drugs or the like will develop into functional or semi-functional quality for corona treatment and will become widely available. A large Swedish pharmaceutical company is starting (right now when this paper is submitted) the tests of a drug they have been using for other diseases previously for its potential in treating corona patients. We cannot make a reliable prediction on how the pandemic situation as a whole will evolve during the following weeks/months/years. All data, all tests and all suggested remedies at the particular date of the submission of this revised paper carry with themselves at least some degree of uncertainty.

In the below, the five level/phase backcasting or "back to the future" exercise is constructed:

Level 1: The overall objective. Vaccination completed for those in need within the Swedish population, 20-26 months from now (5 May 2020). It is beyond the scope of this paper to discuss whether vaccination has ethical problems, e.g., does the income level of an individual affect her/his possibility to have access to the possible vaccine. We understand questions like these are vital for sustainability and its three dimensions (social, economic and environmental).

Level 2: The situation in 14-18 months from now. Vaccination is available to the population.

Level 3: The situation in 10-14 months from now. Large-scale production and manufacturing of the vaccine well underway, e.g., in pharmaceutical organizations or wherever vaccines are manufactured in this type of a war-time case.

Level 4: The situation in 5-10 months from now. Human trials of the vaccine are being conducted in a transparent, iterative and self-critical manner.

Level 5: The situation now-until required. This is where Sweden is right now when this paper is submitted to the journal (5 May 2020). Now Sweden should be or is, we do not know, investing in interdisciplinary and transdisciplinary basic scientific research on COVID-19 mitigation. The integration of the herd-immunity approach from natural science and the backcasting approach from social sciences should be continuously improved in a transparent and science-based manner.

To sum up, this section suggests that the constructed five-level (five step) backcasting exercise for the Swedish case of COVID-19 mitigation can be a possible avenue to make progress in national and global learning for the mitigation of the pandemic. That is, although Sweden would be doing the wrong thing now in its coronavirus mitigation policy, the case of the Swedish Experiment is still important for continuous learning. At the same time, it is acknowledged that the data and its analyses must continuously be updated during the dynamically evolving COVID-19 era. In other words, like WHO (World Health Organization), the Swedish government has publicly acknowledged that a strongly reliable assessment on what response and what strategy was working well in COVID-19 mitigation is a question that can be answered in some three to four years from now.

\section{COVID-19 at the Interface of Natural Science, Social Science and Political Ideology}

The study at hand is an initial attempt to stimulate discussion, dialogue and debate on the potential role of backcasting in national pandemic mitigation policies. Due to climate change, biodiversity loss and increasing ecological footprint of unsustainable economies and industrial societies within the Western modernity, the theme will be more relevant in the near future than now. There are several limitations, problems and weaknesses in our study. In the following, we identify some of the main concerns in the presentation.

COVID-19 pandemic presents a complex challenge for scientific research, public policy and business strategy. The challenge is made worse due to the fact that the phenomenon is new and unknown. Data, knowledge and information on the cause, treatment and societal implications of COVID-19 are emerging and changing on a weekly, even on a daily basis at different places in the world. In classic texts on scientific evolution and progress such as the Kuhnian model of paradigm changes or the Popperian call for falsification (see e.g., [11,19]), in times of extreme uncertainty, bold and provocative arguments can be useful. They stimulate deconstruction, critique and debate. The discussion and debate, e.g., on the limitations of a certain new study, can then result into subsequent 
reconstruction and improved studies conducted by those who have found ways to overcome the limitations of the earlier studies.

We discuss five limitations of our paper below:

(1) The authors are not experts in medical science/medicine

One of the two authors is working on sustainable production and circular economy in a Swedish university. The other one is working in a big industrial production company in Sweden that is active in circular production, circular manufacturing and sustainable production. However, Covid-19 is a very interdisciplinary phenomenon (between sciences) and its mitigation is only possible with a transdisciplinary approach (between different scientific fields and between science and all societal stakeholders, not least the industrial and business community). We continue to prescribe that our initial attempt here is sufficient for delivery and for attracting desired falsification and critique.

\section{(2) Data availability}

When considering the huge requirements for data and materials for conducting a study on COVID-19 mitigation policies, our data is limited. The data should be interdisciplinary, transdisciplinary, global and local, covering several temporal scales, quantitative, qualitative etc. Acknowledging this, it is still fruitful to start the discussion on backcasting as a policy and strategic planning approach to COVID-19 mitigation. When backcasting from social science and herd-immunity from natural science are combined there can be potential for generalization. Situations such as COVID-19, unfortunately, are increasing in likelihood, because of the problems in the past, present and future society-biosphere interactions. Climate change is an illustrative example. Global warming is directly relevant to the case of COVID-19.

\section{(3) The basic nature of the novel coronavirus}

The basic characteristics and features of the novel coronavirus are dynamic, evolving and, to a significant extent, unknown to modern science. Among the best sources for learning for the authors here has been an international television channel CNN and its leading medical experts such as the daily updates by CNN's chief medical expert/correspondent Dr. Sanjay Gupta. The authors interpret that it is possible that the virus has been within the human society for several years. Like all life, it has been spreading, evolving, changing and adapting.

The origin of COVID-19 is in natural ecosystems of which humanity is part. The global economic system is always only a subsystem of the larger parent ecosystem [9]. According to the present knowledge, the publicly available narrative in light of theory within natural science is that the so called "zoonotic transfer" is upstream in cause-and-effect chains in case of corona. This means that the metabolism of a living organism is disrupted and affected in a negative manner when subject to stress. Stress can occur due to habitat loss, deteriorating of biodiversity, climate change, accumulation of wastes and emissions in the biosphere and other negative environmental impacts societies generate.

When the metabolism of bats or of pangolins (animals among those regarded as likely carriers in the wet markets in Wuhan) is low in performance, virus transfer tends to be more likely between living organisms or animals including from animal to human. Although the infamous illegal market in Wuhan China was treating and selling endangered species in a manner that the authors do not want to describe in this paper, the origin, most likely, took place much earlier in "a location unknown". This is because of zoonotic transfer. Despite this limitation concerning the basic nature of COVID-19, we maintain that our message is worthy. The message may help to initiate discussion on the possibility of backcasting as a strategic planning approach in global pandemic mitigation policies. The paper may also be fruitful for integrating natural sciences and social sciences. 
(4) Interdisciplinary and transdisciplinary challenges of COVID-19 mitigation policies

Sustainability science, sustainable development policies and strategies are inherently interdisciplinary and transdisciplinary $[1,3,5,12,13,23-25]$. An example comes from the new and increasingly popular fields within sustainability science; industrial ecology (see e.g., [26-29]) and circular economy [12,13,30-33]. Korhonen et al. (2004) and Cohen-Rosenthal (2000) find that the dominant natural science and engineering perspectives within these new fields should be bridged to more social science-orientated management, organizational, policy and decision-making sciences.

The unsustainable trajectory of the world continues despite many similar concepts and initiatives being launched during the last 50-60 years. Without a real practical connection and link between the two research communities of engineering and natural science on one hand and social sciences, policy, management and organizations on the other hand, industrial ecology and circular economy will not make their best possible contributions. Of course, such relations are many in the history of science and evidence-based decision-making. The acute nature of COVID-19 requires us to revisit and reconsider these historical cases, the data available on them and the scientific research that has been applied to analyze the data.

Correspondingly, backcasting, a strategic planning approach from governance, policy and management fields must be linked to the heard-spread/immunity approach from natural science and medical science. The connection should be made in a transparent, scientific and publicly available manner. Our initial attempt can, at best, start the dialogue along these lines. We encourage the international sustainability science research community to respond to our attempt. We can only learn if the community gives critique toward our work. The work has potential and at the same time has severe limitations and problems in its presentation.

\section{(5) The practical politics/policy—science interdependency}

Sweden is a liberal democratic country. One of the pioneers of this political landscape is the late prime minister Olof Palme. He was murdered on the 28th of February 1986 at the city center of Stockholm. To this date, the murder remains unsolved and a subject of various conspiracy theories. Many of these are relevant considering the political landscape of the world today. The legacy of the prime minister is among the strongest political ideology influences of the entire modernity era of Sweden.

The Palme position was to emphasize the freedom of each and every person as part of the free community embedded within a free open society. He emphasized the original UN declaration on human rights as the cornerstone of governance in Sweden. In Palme, public politics, public policy and governance use human rights for its most important source in learning. Many private organizations have been using the same philosophy in corporate social responsibility (CSR), i.e., in business strategy (see, e.g., the work of Welford, for example, Welford, 1998 etc. [10]). Harvard professor Michael Porter has gone beyond CSR in his work on the concept of shared value [34]. The vision in shared value is that the private sector, the public sector and everybody in the society can work together and simultaneously produce value for all.

It is important to note that just now during the COVID-19 crisis many companies are adopting the role originally assigned to the public sector. For example, CNN news channel aired on April 4th (2020) that the toothpaste giant Colgate is donating 20 million US dollars worth of soap to the World Health Organization (W.H.O.). Two hundred years ago when Mr. Colgate started his business, it started by producing soap. The new soap packaging includes also written instructions on how to wash one's hands properly. It is intended to serve as an educational tool too. Many other multinationals follow suit, e.g., car manufactures producing ventilators, or sport teams flying their private jets loaded with face masks to those in need etc. DANONE, as we saw on 13th April 2020, is now promoting its "one planet one health" program. It is interesting to see how Mercedes Formula 1 team is now producing breathing devices, AS Roma the football/soccer club is devoting significant resources to help the elderly 
in Italy, Ali Baba, Cisco Systems, Vingroup, Richard Branson's Virgin, IKEA and others are engaging in projects that seem to be in accordance with the Porter shared value concept.

Olof Palme made important contributions to the process of improving international human rights and to the process to work toward freedom. He made advances within the Swedish immigration policy, for example. Sweden is now among the most intense nations in the world in its speed of accepting immigrants and refugees from around the world. Sweden may rank in the top five in the world per capita, i.e., how many immigrants are accepted into the country annually per capita. This article has been written in the city of Södertälje located some 40km south from the capitol Stockholm. Södertälje population is around 100,000 . Some $60 \%$ are non-natives. Södertälje economy is a successful one. The Swedish population is around 10.5 million. Södertälje local economy produces more than $10 \%$ of the entire export industry of the country. In other words, $1 \%$ for $10 \%$. This is promoted here in Södertälje as sustainable productivity.

According to the view of the authors of this paper, it is argued that the Palme legacy is now interpreted in the case of the Swedish COVID-19 policy in the following way. We will sum up our understanding of the Palme ideology in the Swedish case in A-D:

(a) When each and every person living in Sweden feels free, she or he feels valuable.

(b) When a person perceives her/himself as valuable, she or he will take responsibility over her/his actions and behavior.

(c) A responsible person who is not subject to coercion, force or command-and-control type of governance and policy or the like, is able to learn and actually will proactively educate her/himself.

(d) A responsible and learning-orientated person will wash her/his hands, will stay home, will volunteer to help the elderly, disabled and, the social service system and the health-care system, will go to bed early, wake up early, eat healthy, exercise and adopt a balanced lifestyle in terms of work and relaxation.

We argue that the Government of Sweden believes the Palme philosophy helps in COVID-19 mitigation. The A-D logic of the above can be important in national COVID-19 mitigation strategy, governance and policy.

Now, the natural science view, the herd-spread or "herd-immunity" approach used as part of the Swedish mitigation efforts has been regarded as the key within the critique the international platform expresses toward the "Swedish Experiment". Today (5 May 2020) CNN aired a story in which W.H.O. stated that "Sweden must do more" than the herd-immunity policy. The first author comes from Finland. Sweden owned Finland for more than 650 years. Finland is a welfare society, e.g., continuously ranked very high in the OECD PISA assessments of the education systems in the world. Finland has adopted a totally different strategy in its COVID-19 mitigation than Sweden.

Finnish policy-makers and scientists along with many other countries in the world including USA etc. are strongly critical concerning the Swedish experiment (although the President of USA seemingly promotes the Swedish approach). For example, still today (5 May 2020) schools are open in Sweden while schools have been closed in Finland for several weeks already. Basically, it can be concluded that the critique states that the Swedish experiment is almost solely based on natural science. However, based on our experience inside the experiment here, we argue that Sweden is actually quite balanced in its usage of natural science (e.g., medical science, biology), social science (e.g., sustainability politics, strategic planning, backcasting) and political ideology (e.g., the Palme legacy). Time will tell the ultimate performance of the Swedish experiment in the mitigation of the COVID-19 crisis and in its ecological (e.g., health), social (e.g., employment, corporate social responsibility) and economic (e.g., performance and the long term well-being of the Swedish economy) dimensions. 


\section{Discussion}

COVID-19 has received more attention from public policy-makers and from big business than climate change. One of the authors was watching the CNN news the other day. The reporter said that imagine where we would be now if global warming would have been taken as seriously as the novel coronavirus. There is value in the comment.

Air pollution is number five in the list of global killers. Typical victims are the poor and the elderly. Common symptoms occur in breathing, in the respiratory system and lungs, i.e., very similar symptoms as with COVID-19. Naturally rich white people suffer from air pollution-caused diseases too, but not nearly to the extent than the old black, hispanic and poor people do. In USA, it is often the poor African people who work on what are now called the "frontlines" in the COVID-19 battle. These include bars, grocery stores, public transportation employees such as bus drivers, cleaners etc. and many of these individuals live in inner city neighborhoods. These parts of the population tend to have worse access to healthcare and social services or high quality educational systems than richer white people.

During the last three months, during the economic and industrial shut-down in many parts of the world, air pollution and also $\mathrm{CO}_{2}$ emissions have been decreasing radically. For example, in India the Himalayan mounting tops are now visible from the distance of over 100 miles (around $160 \mathrm{~km}$ ) with a naked eye. Climate change makes the symptoms of COVID-19 patients more serious. It should also be noted that circular economy and the sharing economy concepts $[10,12,31]$ are now increasing in terms of their value for society and for the economy. In San Antonio and Pittsburg USA, a record number of people are going to the soup kitchens, food banks, the bread lines, i.e., places where food is given to people for free.

About one third of the food produced for human use in the world goes to waste, or is not consumed by humans. The inefficiency and unsustainability in the food consumption is mainly due to what is happening in the Western industrialized developed economies. Simultaneously many people in the developing world suffer from malnutrition. In Pittsburg, the famous multinational organization, the ice hockey team Pittsburg Penguins, is engaging in voluntary work. The Penguins help in the distribution of the waste food to those in need. However, the sharing economy concept has also severe limitations in light of the corona era. Sharing the function and service of the physical product in small groups of individuals (see, e.g., [10]) instead of each individual owning the physical product, like a car, is risky because of the two meter physical distance requirement in the COVID-19 crisis.

However, we maintain that when viewed from the long-term sustainable development perspective, circular economy, sharing economy, corporate social responsibility and the shared value concept are valuable. These concepts can be complementary and work in parallel with COVID-19 mitigation. On Saturday 4 April 2020 (Easter) Apple and Google announced a new collaboration project to help the US and other governments in the world in their COVID-19 situation. We assume that one of the inspirations that Apple and Google must have had was the situation during the spring break in USA. Large student groups largely ignored warnings and had the usual parties on the beaches and elsewhere etc.

Some initial data was then aired on internet and on international television news channels concerning the location of these spring breakers' cell phones after they moved on from the beach. The data was, in a preliminary manner, compared to clusters of hospitalizations, number of COVID-19 confirmed cases, number of intensive care unit admitted patients (with or without confirmed COVID-19), number of deaths etc. We do not know was this comparison rigorous or scientific, or the attempt to compare rigorous or scientific. We assume nobody knows at the date of the submission of our paper to the journal. In any case the location of risk groups in terms of spreading the virus is, we understand, the focus of the new Apple-Google project to be started in May 2020. Naturally, it will face several challenges and limitations like all studies in the complex adaptive society within the biosphere system, e.g., privacy, ethics etc. 
The complexity challenges of the COVID-19 case dictate that the social science originated backcasting and natural science originated herd-immunity approaches face difficulties in research, policy and practice. At the same time, it must be noted that the complexity is also an opportunity towards a new type of interdisciplinary and transdisciplinary collaboration and mutual learning. Backcasting and the herd-immunity concept can serve as each others' complements. Maybe they will be applied in parallel in COVID-19 mitigation, and more extensively than now. The novel coronavirus affects national economies and the global economy in an aggressive and dynamic manner. The impacts occur in different dimensions of societal, industrial and economic development. Backcasting can help in such situations. It has been specifically designed to combat complex, dynamic and long-term challenges such as COVID-19 and unsustainable societal development in general.

\section{Conclusions}

The common, public and global understanding is that the number of per capita Covid-19 infected people as well as the number of per-capita people dead from the novel coronavirus are high in Sweden compared to the rest of the world. At the same time, the government is investing in the natural science-based long-term orientated herd-immunity approach. With the limited amount of data and information available on the COVID-19 situation at this very moment, we conclude as follows. Unlike what is stated in international media, Sweden is not only basing its approach on natural science. Sweden is actually also using ideas and sources that are outside science. We propose that it is reasonable to argue that Sweden is using backcasting, a social science approach to strategic planning. In addition, it seems the underlying political ideology, the human rights emphasis, the so called Olof Palme legacy, is playing an important role too in the overall strategy used by the government.

The available public communication from the government does not state it is using backcasting in its COVID-19 mitigation. But the discussion in this paper indicates many of the key characteristics and features of the Swedish approach are in line with backcasting. Possible reasons why the link between herd-immunity and backcasting are not openly communicated at this time are many. These can include, for example, the interdisciplinary (between sciences) and transdisciplinary (between science and societal stakeholders) nature of backcasting as a strategic planning approach. It must also be noted that the novel Corona virus as a natural phenomenon is still relatively unknown to modern science. All sustainability issues are inherently interdisciplinary and transdisciplinary.

The main message of the paper is that Sweden is using backcasting in Covid-19 mitigation while at the same time using the natural science concept of herd-immunity. Despite many other countries interpreting the Swedish mitigation to be purely based on science, the Swedish approach is based on a complementary relationship between science, politics and political ideology. Whether the approach is successful or not is a question that can be answered long after the publication of this paper.

Author Contributions: J.K. mainly worked on the thesis, the conceptual and scientific research position adopted. B.G. mainly worked on the data gathering, computations, projections and their linkage to the conceptual position. The overall message is a result of close collaboration between the two authors. All authors have read and agreed to the published version of the manuscript

Funding: This research received no external funding.

Conflicts of Interest: The authors declare no conflict of interest.

\section{References}

1. Folke, C. Resilience: The emergence of a perspective for social-ecological systems analyses. Glob. Environ. Chang. 2006, 16, 253-267. [CrossRef]

2. Chertow, M.; Ehrenfeld, J. Organizing Self-Organizing Systems. J. Ind. Ecol. 2013, 16, 13-27. [CrossRef]

3. Odum, E.P. The strategy of ecosystem development. Science 1969, 164, 262-270. [CrossRef] [PubMed]

4. Korhonen, J.; Snäkin, J.-P. Quantifying the relationship of resilience and eco-efficiency in complex adaptive energy systems. Ecol. Econ. 2015, 120, 83-92. [CrossRef] 
5. Robért, K.-H.; Broman, G.; Basile, G. Analyzing the Concept of Planetary Boundaries from a Strategic Sustainability Perspective: How Does Humanity Avoid Tipping the Planet? Ecol. Soc. 2013, 18, 5. [CrossRef]

6. Robèrt, K.-H.; Schmidt-Bleek, B.; Aloise de Larderel, J.; Basile, G.; Jansen, J.L.; Kuehr, R.; Price Thomas, P.; Suzuki, M.; Hawken, P.; Wackernagel, M. Strategic sustainable development-Selection, design and synergies of applied tools. J. Clean. Prod. 2002, 10, 197-214. [CrossRef]

7. Korhonen, J. Industrial ecology in the strategic sustainable development model: Strategic applications of industrial ecology. J. Clean. Prod. 2004, 12, 809-823. [CrossRef]

8. Boulding, K.E. The Economics of the Coming Spaceship Earth. In Environmental Quality Issues in a Growing Economy; Jarrett, H., Ed.; Johns Hopkins University Press: Baltimore, MD, USA, 1966.

9. Daly, H.E. Beyond Growth: The Economics of Sustainable Development; Beacon Press: Boston, MA, USA, 1996.

10. Welford, R. Corporate environmental management, technology and sustainable development: Postmodern perspectives and the need for a critical research agenda. Bus. Strategy Environ. 1998, 7, 1-12. [CrossRef]

11. Ehrenfeld, J.R. Industrial Ecology: Paradigm Shift or Normal Science? Am. Behav. Sci. 2000, 44, $229-244$. [CrossRef]

12. Korhonen, J.; Honkasalo, A.; Seppälä, J. Circular economy: The concept and its limitations. Ecol. Econ. 2018, 143, 37-46. [CrossRef]

13. Korhonen, J.; Nuur, C.; Feldmann, A.; Birkie, S.E. Circular economy as an essentially contested concept. J. Clean. Prod. 2018, 175, 544-552. [CrossRef]

14. Norton, B.; Costanza, R.; Bishop, R.C. The evolution of preferences-Why 'sovereign' preferences may not lead to sustainable policies and what to do about it. Ecol. Econ. 1998, 24, 193-211. [CrossRef]

15. Fagerlind, T.; Stefanicki, M.; Feldmann, A.; Korhonen, J. The distribution of sustainability decision-making in manufacturing networks. Sustainability 2019, 11, 4871. [CrossRef]

16. Potter, S. Exploring Approaches Towards a Sustainable Transport System. Int. J. Sustain. Transp. 2007, 1, 115-131. [CrossRef]

17. Korhonen, J.; Seager, T. Beyond eco-efficiency: A resilience perspective. Bus. Strategy Environ. 2008, 17, 411-419. [CrossRef]

18. Robert, C. Oral Platform Presentation. In Proceedings of the International Society for Ecological Economics (ISEE) Biannual Conference, New Delhi, India, 15-18 December 2006.

19. Kuhn, T. The Structure of Scientific Revolutions; Chicago University Press: Chicago, IL, USA, 1962.

20. Brattebo, H. Towards a methods framework for eco-efficiency analysis? J. Ind. Ecol. 2005, 9, 9-11. [CrossRef]

21. Berkhout, P.H.G.; Muskens, C.; Velthuijsen, J.W. Defining the rebound effect. Energy Policy 2000, $28,425-432$. [CrossRef]

22. Binswager, M. Technological progress and sustainable development: What about the rebound effect? Ecol. Econ. 2001, 36, 119-132. [CrossRef]

23. Rockström, J.W.; Steffen, K.; Noone, Å.; Persson, F.S.; Chapin, E.; Lambin, T.M.; Lenton, M.; Scheffer, C.; Folke, H.; Schellnhuber, B.; et al. A safe operating space for humanity. Nature 2009, 461, 472-475. [CrossRef]

24. Rockström, J.W.; Steffen, K.; Noone, Å.; Persson, F.S.; Chapin, E.; Lambin, T.M.; Lenton, M.; Scheffer, C.; Folke, H.; Schellnhuber, B.; et al. Planetary boundaries: Exploring the safe operating space for humanity. Ecol. Soc. 2009, 14, 32. Available online: http://www.ecologyandsociety.org/vol14/iss2/art32/ (accessed on 15 May 2020). [CrossRef]

25. Jelinski, L.W.; Graedel, T.E.; Laudise, R.A.; McCall, D.W.; Patel, C.K.N. Industrial ecology: Concepts and approaches. Proc. Natl. Acad. Sci. USA 1992, 89, 793-797. [CrossRef] [PubMed]

26. Frosch, R.A.; Gallopoulos, N.E. Strategies for manufacturing. Sci. Am. 1989, 261, 144-152. [CrossRef]

27. Graedel, T.E. On the concept of industrial ecology. Annu. Rev. Energy Environ. 1996, 21, 69-98. [CrossRef]

28. Ayres, R.U. The second law, the fourth law, recycling and limits to growth. Ecol. Econ. 1999, $29,473-483$. [CrossRef]

29. Korhonen, J.; Von Malmborg, F.; Strachan, P.A.; Ehrenfeld, J.E. Management and policy aspects of industrial ecology: An emerging research agenda. Bus. Strategy Environ. 2004, 13, 289-305. [CrossRef]

30. Geissdoerfer, M.; Savaget, P.; Bocken, N.; Hultink, E.J. The circular economy-A new sustainability paradigm? J. Clean. Prod. 2017, 143, 757-768. [CrossRef]

31. Tukker, A. Product services for a resource-efficient and circular economy-A review. J. Clean. Prod. 2015, 97, 76-91. [CrossRef] 
32. Liedaer, M.; Rashid, A. Towards circular economy implementation: A comprehensive review in context of manufacturing industry. J. Clean. Prod. 2016, 115, 36-51. [CrossRef]

33. EMAF (Ellen MacArthur Foundation). Towards the Circular Economy. J. Ind. Ecol. 2013, 2, $23-44$.

34. Porter, M.; Mark, K. Creating Shared Value: How to Fix Capitalism and Unleash a New Wave of Growth. Harv. Bus. Rev. 2011. Available online: https://hbr.org/2011/01/the-big-idea-creating-shared-value (accessed on 15 May 2020).

(c) (1)

(C) 2020 by the authors. Licensee MDPI, Basel, Switzerland. This article is an open access article distributed under the terms and conditions of the Creative Commons Attribution (CC BY) license (http://creativecommons.org/licenses/by/4.0/). 